\title{
PENGAMATAN PERTUMBUH MISELIUM JAMUR TIRAM PUTIH (Pleurotus ostreatus (Jacq). P.kummer) PADA MEDIA DASAR SERBUK GERGAJI DENGAN SUPLEMENTASI AMPAS SAGU
}

\author{
Wahyu Hidayat ${ }^{*}$, Umrah, Meryany Ananda \\ Lab. Bioteknologi Jurusan Biologi Fakultas MIPA, UniversitasTadulako \\ JL. Soekarno-Hatta Tondo palu 94118
}

Corresponding Author :wahyugigantea017@gmail.com

\begin{abstract}
The study of observation of growth media formulation of white oyster mushrooms's mycelium (Pleurotus ostreatus (Jacq.) P.Kummer) on the base with sago pulp supplementation medium was conducted from March to May 2018 at Biotechnology Laboratory, Department of Biology, Faculty of Mathematics and Natural Sciences, Tadulako University. This study were aimed to determine the appropriate formulation and dosage as supplementation of sago pulp with basic media for the growth of the white oyster mushroom mycelium. This study was conducted by Randomized Complete Random Design (RAL), consisted of seven treatments and four replications with basic media and supplementary $M_{0}$ (100\%: without supplements), $M_{1}(95 \%: 5 \%), M_{2}(90 \%$ : $10 \%), M_{3}(85 \%: 15 \%), M_{4}(80 \%: 20 \%), M_{5}$ (75\%:25\%), $M_{6}(70 \%: 30 \%)$. The results showed that the best growth of mycelium on treatment $M_{0}$ and $M_{1}$, mycelium filled the media for 26 days with the average growth of mycelium $M_{0}$ and $M_{1}$ were $0,56 \mathrm{~cm} /$ day. The best formulation and dosage of sago suplementation on the base medium were found in $M_{1}$ (95\% base medium: $5 \%$ sago pulp).
\end{abstract}

Key words: Sago waste, Mycelium, white oyster mushroom

\section{PENDAHULUAN}

Jamur merupakan organisme yang tidak mempunyai klorofil untuk melakukan sintesis makanannya sendiri, hal ini jamur memperoleh makanan yang di hasilkan oleh organisme lain untuk memenuhi kebutuhan nutrisi, salah satunya adalah jamur tiram (Pleurotus ostreatus) yang banyak tumbuh di daerah sub-tropis (Suparti dan Marfuah, 2015). Pertumbuhan jamur di alam hidup pada substrat secara saprofit yang mengandung zat nutrisi selulosa dimana banyak terdapat pada kayu lapuk seperti pada media serbuk gergaji (Imelda dkk, 2015). Menurut Suharnowo dkk, (2012), secara umum 
pertumbuhan jamur hidup dengan cara menyerap nutrisi dari substrat berupa selulosa, glukosa, lignin, protein serta senyawa karbohidrat.

Budidaya jamur tiram di media tanam baik pada skala kecil atau skala besar secara umum menggunakan serbuk gergaji sebagai substrat dasar media tumbuh jamur tiram, karena mengandung selulosa, lignin, karbohidrat dan serat (Suriawira, 2002). Penggunaan serbuk gergaji sebagai media tumbuh jamur mulai berkurang karena kesulitan untuk mendapatkan serbuk gergaji (Wahida dan Saputra, 2015). Hal ini disebabkan karena sulitnya meubel memperoleh bahan kayu serta banyaknya produk rumah tangga yang terbuat dari bahan plastik sehingga ketersediaan serbuk gergaji sulit di peroleh untuk memenuhi pembuatan media jamur tiram (Arifin dkk, 2014).

Salah satu bahan alternatif untuk pertumbuhan miselium jamur tiram putih adalah ampas sagu. Ampas sagu merupakan jenis limbah perkebunan yang berasal dari proses penyaringan pati tepung sagu. Berdasarkan penelitian (Sangadji dkk, 2008), pada ampas sagu terdapat komponen nutrisi berupa hemiselulosa $14.6 \%$, selulosa $36,3 \%$, lignin $9,7 \%$, silika $3,3 \%$, serat kasar 20,3 dan abu 4,6\%. Adapun kandungan nutrisi yang yang lain terdapat pati berkisar 58\% (Vincent et al., 2015).

Menurut Islami dkk, (2013), media tanam jamur yang mengandung selulosa dapat dijadikan substrat yang baik untuk pertumbuhan jamur. Kandungan selulosa dapat memacu pembentukan enzim selulase yang dibutuhkan dalam pembentukan tubuh buah jamur. Pada penelitian ini diharapkan dengan penambahan ampas sagu sebagai media tumbuh jamur tiram dapat memacu pertumbuhan miselium jamur tiram. Penelitian ini bertujuan untuk mengetahui formulasi ampas sagu dengan media dasar sebagai pertumbuhan miselium jamur tiram putih serta dosis yang sesuai sebagai sumplementasi ampas sagu dengan media dasar untuk pertumbuhan miselium jamur tiram putih yang maksimal.

\section{BAHAN DAN ALAT METODE}

Bahan yang digunakan ampas sagu, serbuk gergaji, kapur $\left(\mathrm{CaCO}_{3}\right)$, aquades, inokulum jamur tiram putih (Pleurotus ostreatus), alkohol 70\%, botol, kertas lakmus, label, karet gelang, plastik dan aluminium foil.

Alat-alat yang digunakan autoklaf, botol kultur, neraca analitik, spatula, ayakan 0,04 mm, pisau, pinset, jangka sorong, bunsen, gelas ukur $300 \mathrm{ml}$, enkas dan laminar air flow.

\section{Rancangan penelitian}

Penelitian ini didesain dalam Rancangan Acak Lengkap (RAL), terdiri dari tujuh perlakuan dan empat kali ulangan, susunan perlakuan sebagai berikut; $M_{0}$ ( Media dasar 100\%, tanpa suplemen), $M_{1}$ (Media dasar 95\% + Suplemen 5\%), $\mathrm{M}_{2}$ (Media dasar 90\% + Suplemen 10\%), $M_{3}$ (Media dasar $85 \%+$ Suplemen 15\%), $\mathrm{M}_{4}$ (Media dasar $80 \%+$ 
Hidayat, dkk. Biocelebes. Desember. 2019. Volume 13 Nomor 3, Halaman 218-225

Suplemen 20\%), $\mathrm{M}_{5}$ (Media dasar $75 \%+$ Suplemen 25\%), $M_{6}$ (Media dasar 70\% + Suplemen 30\%). Media dasar berupa Serbuk gergaji dan suplemen berupa Ampas Sagu.

\section{Penyiapan media}

Media perlakuan terdiri dari campuran, serbuk gergaji kapur $\left(\mathrm{CaCO}_{3}\right)$ dengan suplemen, sesuai dosis seperti susunan perlakuan diatas. Media yang telah dicampur, dikomposkan selama 24 jam.

Botol kultur diisi media perlakuan sebanyak 200 g. kemudian disterilkan kedalam autoklaf dengan suhu $121^{\circ} \mathrm{C}$ selama 30 menit. Media siap di inokulasikan

\section{Inokulasi}

Botol kultur yang berisi media perlakuan diinokulikasn dengan inokulum bahan murni jamur tiram, menggunakan spatula, secara aseptik.

\section{Inkubasi}

Botol kultur yang telah di inokulasikan, selanjutnya di inkubasi sampai semua miselium memenuhi botol kultur perlakuan. Media yang berisi inokulum pada botol di inkubasi pada enkas. Tujuan inkubasi botol media adalah untuk menumbuhkan miselium jamur tiram. Dilakukan pengamatan parameter selama inkubasi.

\section{Parameter Pengamatan}

\section{a. Pertumbuhan miselium pada media}

Pengamatan pertumbuhan miseliu jamur tiram dilakukan pada setiap botol perlakuan, Selama inkubasi
Pertumbuhan miselium dalam botol dan dalam baglog dapat dihitung dengan penggunakan rumus (Zadoks dan Schein,1979):

$$
\mathrm{R}=\frac{\mathrm{L} 2-\mathrm{L} 1}{\mathrm{~T}}
$$

\section{Keterangan :}

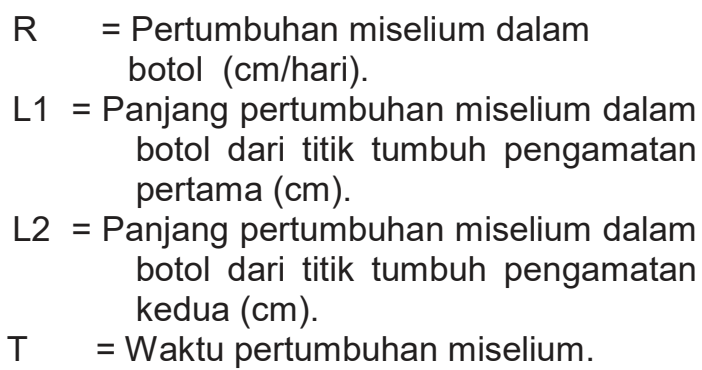

b. Waktu inkubasi sampai miselium memenuhi media

Waktu pertumbuhan miselium jamur tiram diamati mulai dari awal inkubasi sampai miselium memenuhi media botol kultur.

\section{c. Uji viabilitas bibit}

Uji viabilitas bertujuan untuk mengetahui daya tumbuh benih melalui kemampuan pertumbuhan miselium jamur pada media produksi.

\section{HASIL}

Pertumbuhan miselium pada botol kultur

Berdasarkan Gambar 1, perlakuan $\mathrm{M}_{0}$ dan $\mathrm{M}_{1}$ memiliki rata-rata pertumbuhan miselium yang sama yaitu $0,56 \mathrm{~cm}$ per hari. Pertumbuhan miselium yang terendah terdapat pada perlakuan $M_{6}$ dengan rata-rata pertumbuhan $0,46 \mathrm{~cm}$. 


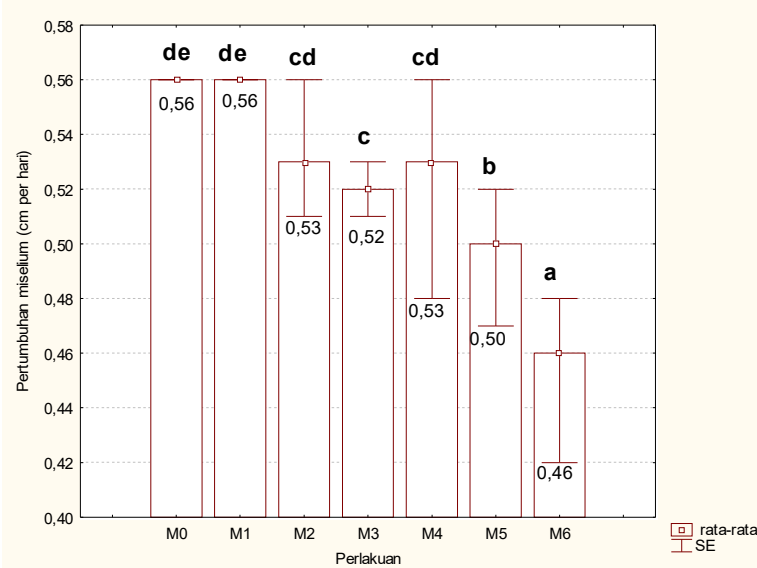

Gambar 1. Diagram pertumbuhan miselium jamur tiram pada botol terhadap semua perlakuan.

Secara statistik pertumbuhan miselium tertinggi pada perlakuan $M_{1}$ (memakai ampas sagu) akan tetapi tidak berbeda nyata dengan perlakuan $M_{0}$ (tanpa ampas sagu) memiliki pertumbuhan yang sama. Hal ini menunjukan dengan penambahan ampas sagu memberikan pengaruh pertumbuhan miselium.

Pengukuran pertumbuhan miselium dilakukan setiap dua hari sekali sampai salah satu perlakuan memenuhi dasar botol dengan pengukuran sampai pada hari ke-26.

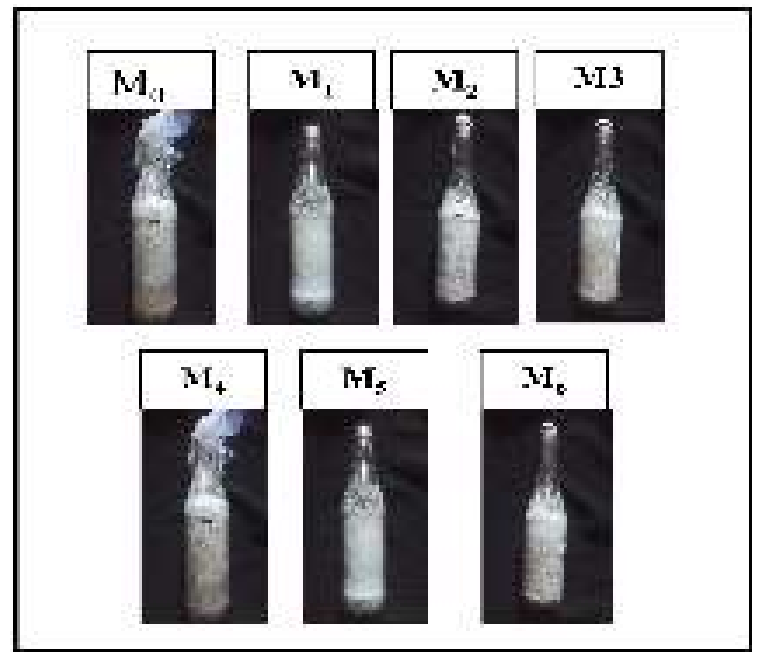

Gambar 2. Pertumbuhan miselium jamur tiram pada botol terhadap semua perlakuan

\section{Waktu Inkubasi \\ Sampai Miselium Memenuhi Media}

Pertumbuhan miselium pada media membutuhkan waktu inkubasi yang berbeda dari ke-7 perlakuan. Pengamatan waktu inkubasi miselium memenuhi media dilakukan selama 38 hari.

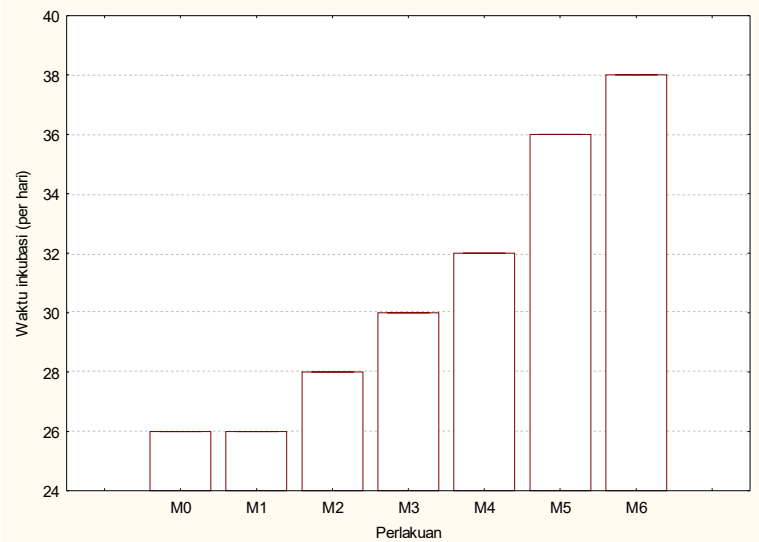

Gambar 3. Diagram waktu inkubasi miselium memenuhi media selama 38 hari setelah inokulasi.

Berdasarkan Gambar 3, menunjukan pertumbuhan miselium Pada perlakuan $\mathrm{M}_{0}$ (serbuk gergaji $100 \%$ : tanpa suplemen) dan $M_{1}$ (serbuk gergaji 95\% : suplemen $5 \%$ mempunyai pertumbuhan miselium yang paling cepat memenuhi media pada hari ke $26, M_{2}$ (serbuk gergaji $90 \%$ : suplemen 10\%) memenuhi media pada ke-28, $M_{3}$ (serbuk gergaji $85 \%$ : suplemen 15\%) miselium memenuhi media pada hari ke-30, $\mathrm{M}_{4}$ (serbuk gergaji $80 \%$ : suplemen $20 \%$ ) miselium memenuhi media pada hari ke-32, $M_{5}$ (serbuk gergaji $80 \%$ : suplemen $25 \%$ ) miselium memenuhi media pada hari ke-36 dan perlakuan $\mathrm{M}_{6}$ (serbuk gergaji $70 \%$ : suplemen $30 \%$ ) miselium memenuhi media pada hari ke-38 setelah inokulasi. 


\section{Uji viabilitas Inokulum Pada Media Produksi}

Uji viabilitas bertujuan untuk melihat kualitas bibit atau inokulum miselium jamur tiram putih dengan melihat pertumbuhan miselium yang ditumbuhkan pada media produksi yang terdiri dari bahan serbuk gergaji, bekatul dan kapur. Inokulum yang ditanam pada media produksi diinkubasi selama 46 hari.

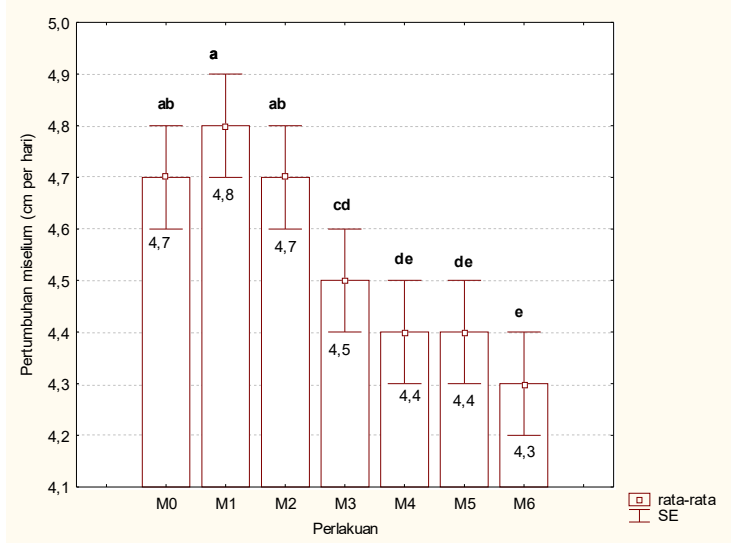

Gambar 4. Diagram Pertumbuhan miselium pada uji viabilitas terhadap media produksi.

Berdasarkan gambar 4, menunjukan perlakuan $M_{1}$ (serbuk gergaji 95\% : suplemen $5 \%$ memiliki rata-rata pertumbuhan yang tinggi yaitu $4,8 \mathrm{~cm}$ per hari adapun pertumbuhan miselium yang rendah pada perlakuan $\mathrm{M}_{6}$ (serbuk gergaji $70 \%$ : ampas sagu $30 \%$ ) dengan rata-rata pertumbuhan $4,3 \mathrm{~cm}$ per hari. Adapun pengamatan pertumbuhan bibit inokulum pada media produksi dilakukan setiap 1 kali dalam 4 hari. Pengamatan pertumbuhan miselium bibit pada media produksi dilakukan selama 46 hari.

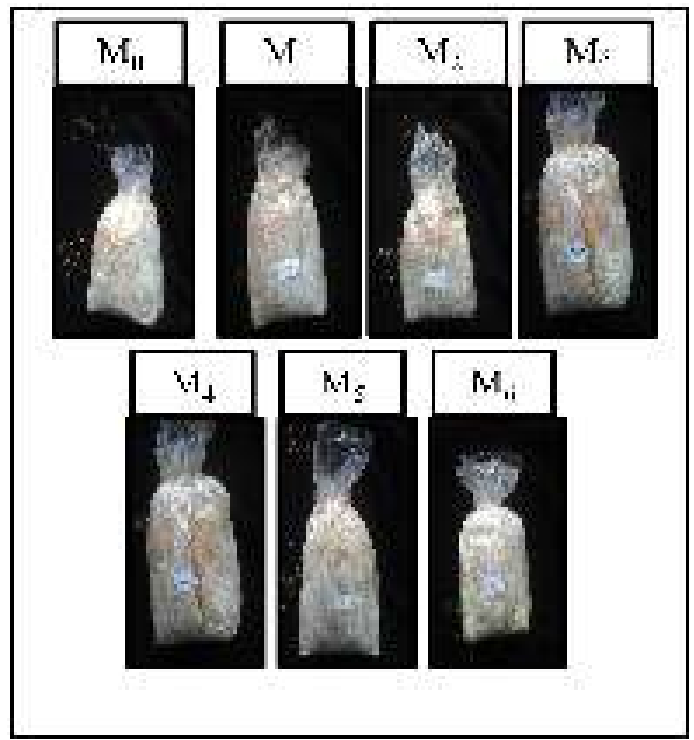

Gambar 5. Gambar Pertumbuhan miselium jamur tiram putih pada media produksi.

Pertumbuhan miselium menunjukan bibit inokulum ampas sagu yang ditumbuhkan pada media produksi dapat digunakan sebagai sumber bibit yang baik.

\section{PEMBAHASAN}

Pengukuran

pertumbuhan

miselium pada botol mengunakan mistar setiap 2 hari sekali sampai miselium memenuhi media. Pengukuran pertumbuhan panjang miselium diukur dari bagian atas permukaan media. Menurut Suharnowo dkk (2012), pengukuran pertumbuhan miselium pada polybag diukur pada bagian atas media sampai pada bagian bawah permukaan polybag. Menurut Suparti dan Karimawati (2017), miselium jamur tiram tumbuh berwarna putih yang seragam dan sedikit lebih lebat.

Berdasarkan hasil yang diperoleh menunjukan bahwa miselium dapat tumbuh pada setiap perlakuan walaupun terdapat perbedaan pertumbuhan miselium 
memenuhi media. Media yang memberikan pengaruh pertumbuhan miselium lebih cepat ialah media tanam pada perlakuan $\mathrm{M}_{0} \quad$ (media serbuk gergaji $100 \%$ tanpa suplemen) dengan rata-rata pertumbuhan miselium $0,56 \mathrm{~cm} 2$ hari dan $\mathrm{M}_{1}$ (serbuk gergaji $95 \%$ : suplemen $5 \%$ ) dengan ratarata pertumbuhan $0,56 \mathrm{~cm}$ per 2 hari dengan masa inkubasi selama 26 hari, sedangkan $M_{6}$ (serbuk gergaji $70 \%$ : suplemen $30 \%$ ) menunjukan pengaruh pertumbuhan miselium yang rendah dengan rata-rata pertumbuhan $0,45 \mathrm{~cm}$ per 2 hari.

Hasil dari data pertumbuhan yang diperoleh menunjukan bahwa semakin tinggi konsentrasi ampas sagu yang diberikan pada media, semakin rendah pertumbuhan miselium pada media tersebut. Hal tersebut juga terlihat pada pengamatan waktu inkubasi yang dibutuhkan miselium jamur tiram putih memenuhi media. Pada perlakuan $M_{0}$ tanpa suplemen ampas sagu dan $M_{1}$ suplemen ampas sagu 5\% memiliki waktu pertumbuhan meselium yang sama yaitu memenuhi media pada hari ke-26.

Perlakuan $M_{0}$ dan $M_{1}$ memiliki Pertumbuhan dan waktu memenuhi media yang tidak berbeda nyata. Hal ini disebabkan pada media yang ditambahkan ampas sagu memiliki tekstur yang lengket sehingga media menjadi padat. Sifat lengket dan padatnya media sebabkan oleh kandungan ampas sagu.

Kandungan nutrisi ampas sagu menurut Adeni et al (2012), terdiri komponen pati $30 \%$ - $45 \%$ dan abu $4 \%$. Adapun komponen lain selulosa 23,5\%, hemiselulosa $8,19 \%$, lignin $6,3 \%$ dan nutrisi yang lain berupa 2,3\% (Vincent et al, 2015). Menurut Swinkels, (1985), Pati sagu mengadung $27 \%$ amilosa dan amilopektin $73 \%$. Sifat amilosa yang keras dan amilopektin yang lengket mengakibatkan media menjadi padat dan keras. Hal ini terjadi pada saat sterilisasi media pada suhu $121{ }^{\circ} \mathrm{C}$ sehingga pati pada ampas sagu mengembang dan lengket sehingga media menjadi padat.

Menurut Rosmawati (2013), sulitnya kapang menghidrolisis amilum yang terdapat pada ampas sagu, dikarenakan amilosa pada pati sagu mempunyai sifat yang keras sedangkan amilopektin bersifat lengket sehingga sulit untuk di degradasi.

Pertumbuhan miselium juga dipengaruhi oleh beberapa faktor seperti suhu dan kelembapan tempat inkubasi. Menurut Widyastuti dan Tjokrokusumo (2008), pertumbuhan miselium yang baik pada suhu $24^{\circ} \mathrm{C}-29^{\circ} \mathrm{C}$ dengan kelembapan $90 \%-100 \%$ dan tingkat keasaman $\mathrm{pH} 6-7$ dengan menggunakan kapur (calsium karbonat).

Bibit inokulum yang dihasilkan pada media dasar dan suplemen diterapkan pada media prduksi yang terdiri dari serbuk gergaji, dedak padi. Menurut Steviani (2011), viabilitas inokulum jamur merupakan daya tumbuh benih yang ditunjukkan melalui kemampuan pertumbuhan miselium jamur pada media. Oleh karena itu penting melakukan 
pemeliharaan sumber inokulum jamur. Pada uji viabiliatas inokulum jamur tiram putih yang ditumbuhkan pada media produksi dengan konsentrasi media yang sama menunjukan pertumbuhan miselium yang berbeda pada setiap inokulum yang di inokulasikan. Pertumbuhan miselium yang paling baik pada perlakuan $M_{1}$ (serbuk gergaji 95\% : suplemen 5\%) dengan panjang rata-rata miselium $4,8 \mathrm{~cm}$ per hari, sedangkan pada perlakuan $M_{0}$ (serbuk gergaji 100\% : tanpa suplemen) dan $\mathrm{M}_{2}$ (serbuk gergaji $90 \%$ : suplemen $10 \%$ memiliki rata-rata pertumbuhan miselium yang sama yaitu $4,7 \mathrm{~cm}$ per 4 hari dengan masa inkubasi selama 46 hari (gambar4). Hal ini menunjukan bibit inokulum ampas sagu yang ditumbuhkan pada media produksi dapat digunakan sebagai sumber bibit yang baik.

Miselium jamur tiram putih (Pleurotus ostreatus (Jacq.) P.Kummer.) pada setiap perlakuan mampu tumbuh dengan pertumbuhan miselium dan waktu memenuhi media yang berbeda. Formulasi ampas sagu pada media dasar sebagai pertumbuhan miselium jamur tiram putih yang baik yaitu pada perlakuan $\mathrm{M}_{0}$ (media dasar $100 \%$ dan suplemen ampas sagu) $0,56 \mathrm{~cm}$ per hari dan $\mathrm{M}_{1}$ (media dasar $95 \%$ dan suplemen ampas sagu $5 \%$ ) dengan rata-rata pertumbuhan miselium $0,56 \mathrm{~cm}$ per hari.

Dosis yang sesuai sebagai suplementasi ampas sagu dengan media dasar untuk pertumbuhan miselium jamur tiram putih yang maksimal yaitu $5 \%$.
Semakin tinggi penambahan suplemen ampas sagu pada setiap perlakuan memberi pengaruh lambatnya pertumbuhan miselium pada media.

\section{UCAPAN TERIMAKASIH}

Terima kasih kepada Laboran (Sami Bukang S.P dan Dra. Happy) di laboratorium. Bioteknologi Fakultas Matematika dan IImu Pengetahuan Alam Universitas Tadulako.

\section{DAFTAR PUSTAKA}

Adeni, A.S.D., Bujang, B.K., Hassan, A.M., end Aziz-abd, S. (2012). Recovery of glucose from residual starch of sago hampas for bioethanol production. BioMed Research International. 20 (13), 1-8.

Arifin, I., Isnawati. dan Fitrihidajati, $\mathrm{H}$. (2014). Penggunaan Limbah Kapas Industri Kain dengan Tambahan Bekatul Sebagai Alternatif Bahan Media Tanam Jamur Tiram Putih ( Pleurotus ostreatus ). Lenterabio. 3 (3), 216-221.

Islami .A, Purnomo A.S., dan Sukesi. (2013). Pengaruh Komposisi Ampas Aren dan Kayu Sengon Sbagai Media Pertumbuhan Terhadap Nutrisi Jamur Tiram (Pleurotus ostreatus). ). Sains dan Seni Pomoits 2 (1), 2-5.

Rosmawati. (2013). Isolasi kapang pendegradasi amilum pada ampas sagu (Metroxylon sagoo) secara invitro. Biologi Science dan Education. 3 (3), 25-34.

Sangadji, I., Parakkasi, A., Wiryawan, G.K.., dan Haryanto, B. (2008). Perubahan Nilai Nutrisi ampas Sagu Selam Pada Fase Pertumbuhan Jamur Tiram Putih (Pleurotus 
ostreatus) yang Berbeda. IImu Ternak. 8 (1), 31-34.

Suparti dan Marfuah. (2015). Produktivitas jamur tiram putih (Pleurotus ostreatus) pada media limbah sekam padi dan daun pisang kering sebagai media alternatif. Bioeksperimen. 1 (2), 37-44.

Suparti dan Karimawati, N. (2017). Pertumbuhan bibit Fo jamur tiram dan jamur merang pada media umbi talas pada konsentrasi yang berbeda. Bioeksperimen. 3 (1), 6472.

Steviani, S. (2011). Pengaruh Penambahan Malase Dalam Berbagai Media pada Jamur Tiram Putih (Pleurotus ostreatus). Skiripsi. Fakultas Pertanian. Universitas Sebelas Maret. Surakarta.

Suharnowo, Lukas, S., Budipramana, dan Isnawati. (2012). Pertumbuhan Miselium Dan Produksi Tubuh Buah Jamur Tiram Putih (Pleurotus Ostreatus) Dengan Memanfaatkan Kulit Ari Biji Kedelai Sebagai Campuran Pada Media Tanam. LenteraBio 1 (3), 125-30.

Suriawiria, U. H. (2002). Budi Daya Jamur Tiram. Jakarta: Kanisius.

Swinkels, J.J.M. (1985). Sourch of starch, its chemistry and physics. Di dalam G.M.A. Van Beynum and J. A. Roels. 1985. Strach Convention Technology. New York: Marcel Dekker.

Vincent, M., Senawi, A.R.B., Esut, E., Nor, M.N end Adeni, A.S.D. (2015). Sequential saccharification and simultaneous fermentation (SSSF) of sago hampas for the production of bioethanol. Malaysiana. 44 (6), 899904.

Wahidah, F. B., dan Saputra, A. F. (2015). Perbedaan pengaruh media tanaman serbuk gergaji dan jerami padi terhadap pertumbuhan jamur turam putih. Biogenesi. 3 (1), 11-15.

Widyastuti, N., Dan Tjokrokusumo, D. (2008). Aspek Lingungan Sebagai Faktor Penentu Keberhasilan Budidaya Jamur Tiram. Aspek Lingkungan Sebagai Teknologi Linkungan. 9 (3), 287-293.

Zadoks, J.C. and R.D. Schein. (1979). Epidemiology and Plant Disease Management. New York: Oxford University Press. 